\title{
UJI AKTIVITAS EKSTRAK DAN FRAKSI TUNIKATA Lissoclinum patella TERHADAP PERTUMBUHAN MIKROBA Escherichia coli, Staphylococcus aureus, DAN Candida albicans
}

\author{
Yunike E. Ngantung ${ }^{1)}$, Herny E. Simbala ${ }^{1)}$, Henki Rotinsulu ${ }^{1)}$ \\ ${ }^{1)}$ Program Studi Farmasi FMIPA UNSRAT Manado, 95115
}

\begin{abstract}
Tunicate is one of the marine biota that has the potential to be utilized as a search for bioactive compounds, as prospective drugs in the pharmaceutical world. This study aims to determine the antimicrobial activity of extracts and fractions of Tunicates Lissoclinum patella obtained from the waters of Tumbak Village against the growth of microbes Escherichia coli, Staphylococcus aureus and Candida albicans. Samples were extracted by maceration using ethanol as a solvent. Fractionation using n-hexane, chloroform and methanol. Antimicrobial activity was tested using the disc diffusion method (Kirby and Bauer). The results showed that the ethanols extract, $n$-hexane fraction, chloroform fraction, methanol fraction effectively inhibited the growth of microbes Escherichia coli, Staphylococcus aureus, Candida albicans with moderate inhibition strength categories based on Davis and Stout theory.
\end{abstract}

Keywords : Tunicata, Lissoclinum patella, antimicrobial, Candida albicans, Escherichia coli, Staphylococcus aureus.

\begin{abstract}
ABSTRAK
Tunikata merupakan salah satu biota laut yang berpotensi untuk dimanfaatkan sebagai bahan pencarian senyawa bioaktif, calon obat di dunia farmasi. Penelitian ini bertujuan untuk mengetahui aktivitas antimikroba dari ekstrak dan fraksi Tunikata Lissoclinum patella yang diperoleh dari perairan Desa Tumbak terhadap pertumbuhan mikroba Escherichia coli, Staphylococcus aureus dan Candida albicans. Sampel diekstraksi dengan cara maserasi menggunakan pelarut etanol. Fraksinasi menggunakan pelarut n-Heksan, kloroform dan metanol. Aktivitas antimikroba diuji menggunakan metode disc diffusion test (Kirby dan Bauer). Hasil penelitian menunjukkan bahkwa ekstrak etanol, fraksi n-Heksan, fraksi kloroform, fraksi metanol efektif menghambat mikroba Escherichia coli, Staphylococcus aureus, Candida albicans dengan kategori kekuatan daya hambat sedang berdasarkan teori Davis dan Stout.
\end{abstract}

Kata kunci : Tunikata, Lissoclinum patella, antimikroba, Candida albicans, Escherichia coli, Staphylococcus aureus. 
PHARMACON- PROGRAM STUDI FARMASI, FMIPA, UNIVERSITAS SAM RATULANGI, Volume 8 Nomor 4 November 2019

\section{PENDAHULUAN}

Laut Indonesia memiliki banyak sumber daya alam termasuk banyaknya keanekaragaman jenis biota laut (Nofiani, 2008). Keanekaragaman ini memberi peluang untuk memanfaatkan biota laut sebagai sumber pengobatan. Menurut Rasyid (2008) pemanfaatan potensi ini dalam hal pengobatan belum optimal, padahal, potensi yang sangat besar dalam menghasilkan senyawa-senyawa aktif berasal dari organisme laut. Tunikata merupakan salah satu komponen biota penyusun terumbu karang yang mempunyai potensi bioaktif, sehingga menjadikan tunikata target yang sangat menarik karena keanekaragamannya yang tinggi dan unik diantara invertebrata laut karena menghasilkan sejumlah besar senyawa yang mengandung nitrogen (Wang and Namikoshi, 2007). Berbagai penelitian menunjukkan bahwa organisme laut memiliki potensi yang sangat besar dalam menghasilkan senyawa-senyawa aktif yang dapat digunakan sebagai bahan baku obat. Beberapa organisme laut yang diketahui dapat menghasilkan senyawa aktif, salah satunya adalah tunikata. Organisme ini diketahui dapat menghasilkan sejumlah besar produk laut yang bersifat alami, juga mampu menunjukkan keragaman senyawa kimia yang sangat besar (Thakur and Muller, 2004).

Tunikata merupakan salah satu biota laut yang belum mendapat perhatian yang serius, namun mempunyai potensi yang cukup besar di perairan Indonesia. Tunikata potensial dijadikan sebagai bahan eksplorasi pencarian senyawa bioaktif baru sebagai calon obat untuk dunia farmasi (Wewengkang et al., 2014). Tunikata termasuk ke dalam kelompok hewan invertebrata di ekosistem terumbu karang yang banyak menghasilkan senyawa bioaktif. Senyawa bioaktif tunikata berfungsi sebagai pertahanan diri dan juga berfungsi bagi kehidupan manusia, yaitu sebagai antikanker, antiinflamasi, dan antimikroba (Khoeri, 2009).

Berdasarkan penelusuran pustaka diketahui belum ada penelitian mengenai aktivitas menghambat pertumbuhan mikroba dari Tunikata Lissoclinum patella. Sehingga peneliti tertarik untuk melakukan penelitian aktivitas menghambat pertumbuhan mikroba dari ekstrak dan fraksi Tunikata Lissoclinum patella dari perairan Desa Tumbak, Kecamatan Posumaen, Kabupaten Minahasa Tenggara, Sulawesi Utara.

\section{METODOLOGI PENELITIAN}

\section{Waktu dan Tempat \\ Penelitian}

Penelitian ini dilaksanakan pada bulan Maret-Juni 2019 di Laboratorium lanjutan Program Studi Farmasi Fakultas Matematika dan Ilmu Pengetahuan Alam Universitas Sam Ratulangi.

\section{Bentuk Penelitian}

Bentuk Penelitian ini ialah eksperimental laboratorium yang akan menguji komponen yang diekstrak dari Tunikata Lissoclinum patella sebagai antimikroba yang diperoleh dari perairan Desa Tumbak, Kecamatan Posumaen, Kabupaten Minahasa Tenggara, Sulawesi Utara. 
PHARMACON- PROGRAM STUDI FARMASI, FMIPA, UNIVERSITAS SAM RATULANGI,

Volume 8 Nomor 4 November 2019

\section{Alat dan Bahan}

Alat

Alat yang digunakan dalam penelitian ini yaitu masker, sarung tangan, pisau, gunting, telenan, Scuba Diving, Zipperbag, Aluminium Foil, label, Erlenmeyer (Pyrex), corong pisah, gelas ukur (Pyrex), gelas kimia (Pyrex), tabung reaksi, oven, timbangan analitik (Kem), cawan petri, autoklaf (Autoclaf KT-30s), pinset, batang pengaduk, pembakar spiritus, pipet tetes, mikro tub, Laminar Air Flow (Clean Bench), lemari pendingin, Fortex, incubator (N-biotek), mikropipet, jangka sorong, penggaris, vial, pot salep, kertas cakram, spidol permanen, tissue, kertas saring, cool box, kamera untuk keperluan dokumentasi.

\section{Bahan}

Bahan-bahan yang digunakan yaitu Tunikata Lissoclinum patella, bakteri uji Staphylococcus aureus, Escherichia coli, jamur uji Candida albicans, etanol 96\%, nHeksan, kloroform, metanol, akuades, ekstrak beef, pepton, $\mathrm{NaCl}$, agar, Kloramfenikol.

\section{Prosedur Penelitian}

\section{Pengambilan Sampel}

Sampel Tunikata Lissoclinum patella diambil dari perairan Desa Tumbak, Kecamatan Posumaen, Kabupaten Minahasa Tenggara, Sulawesi Utara menggunakan alat bantu (masker, tabung udara, snorkel, dan fins). Sampel dibersihkan dari kotoran yang menempel disekitarnya, difoto lalu dimasukkan kedalam Zipperbag, Sampel dipotong kecil-kecil dan diekstraksi dengan cara maserasi dengan etanol $96 \%$ lalu diberi label serta nomor sampel kemudian disimpan dalam cool box. Sebagian dari sampel disimpan dalam vial untuk diawetkan sebagai voucher.

\section{Ekstraksi}

Tunikata Lissoclinum patella sebanyak $400 \mathrm{~g}$ diekstraksi dengan cara maserasi. Sampel di bersihkan, dipotong kecil-kecil lalu dimasukkan ke dalam botol dan direndam dengan larutan etanol 96\% sampai sampel terendam secara keseluruhan dan dibiarkan selama 24 jam. Sampel yang direndam disaring dengan menggunakan kertas saring menghasilkan filtrat 1 dan debris 1 . Debris 1 direndam dengan larutan etanol $96 \%$ sampai sampel terendam secara keseluruhan kemudian dibiarkan selama 24 jam. Sampel tersebut disaring menggunakan kertas saring menghasilkan filtrat 2 dan debris 2. Debris 2 kemudian direndam dalam larutan etanol 96\% sampai sampel terendam secara keseluruhan dan dibiarkan selama 24 jam, sampel tersebut disaring menggunakan kertas saring menghasilkan filtrat 3 dan debris 3. Filtrat 1, 2 dan 3 dicampur menjadi satu kemudian disaring, lalu dimasukkan kedalam Oven sehingga didapat ekstrak kasar Tunikata Lissoclinum patella kemudian ditimbang menggunakan timbangan analitik. Ekstrak kasar yang diperoleh yaitu 11,4 g selanjutnya digunakan dalam fraksinasi dan pengujian aktivitas antimikroba.

\section{Fraksinasi}

Ekstrak kasar sebanyak $6 \quad \mathrm{~g}$ Lissoclinum patella dimasukkan kedalam 
erlenmeyer, kemudian dilarutkan dengan metanol $80 \%$ sebanyak $100 \mathrm{~mL}$. Setelah larut, dimasukan kedalam corong pisah dan ditambahkan pelarut n-Heksan sebanyak 100 $\mathrm{mL}$. Setelah itu dikocok sampai homogen. Dibiarkan hingga terbentuk lapisan metanol dan lapisan $\mathrm{n}$-Heksan. Masing-masing lapisan ditampung dalam wadah yang berbeda. Lapisan n-Heksan selanjutnya dimasukkan kedalam oven hingga kering, lalu ditimbang dan diperoleh ekstrak fraksi n-Heksan sebanyak 0,1495gr.

Lapisan metanol ditambahkan akuades $100 \mathrm{~mL}$, dipartisi dengan pelarut kloroform dengan perbandingan 1:1 v/v dalam corong pisah dikocok sampai homogen. Dibiarkan hingga terbentuk dua lapisan yaitu lapisan metanol dan lapisan kloroform. Masing-masing lapisan ditampung dalam wadah yang berbeda. Lapisan kloroform selanjutnya dimasukkan kedalam oven hingga kering lalu ditimbang dan diperoleh fraksi kloroform sebanyak 0,0498gr. Lapisan metanol dimasukkan kedalam oven hingga kering lalu ditimbang dan diperoleh fraksi methanol sebanyak 0.1268. Ketiga fraksi yang diperoleh digunakan dalam pengujian antimikroba dan dihitung nilai rendemen dari masing-masing fraksi dengan persamaan:

$$
\text { Rendemen }=\frac{\text { Berat hasil ekstrak }}{\text { Berat ekstrak awal }} \times 100 \%
$$

\section{Sterilisasi Alat}

Alat-alat gelas yang digunakan dalam penelitian aktivitas antimikroba ini disterilkan terlebih dahulu dengan menggunakan autoklaf pada suhu $121{ }^{\circ} \mathrm{C}$ selama 15 menit, pinset dibakar dengan pembakaran di atas api langsung dan media disterilkan di autoklaf pada suhu $121{ }^{\circ} \mathrm{C}$ selama 15 menit (Ortez, 2005).

\section{Pembuatan Media B1}

Ditimbang Pepton 0,5 g, ekstrak daging $0,3 \mathrm{~g}$ (meat extract), Natrium klorida $0,3 \mathrm{~g}$ dilarutkan dalam metanol sebanyak $100 \mathrm{~mL}$ menggunakan Erlenmeyer, dikocok sampai homogen. Media yang telah homogen kemudian disterilkan dengan menggunakan autoklaf pada suhu $121^{\circ} \mathrm{C}$ selama 15 menit. Dipipet $1 \mathrm{~mL}$ media cair B1, kemudian masukkan dalam tabung reaksi dan tutup dengan aluminium foil. Media cair B1 siap digunakan sebagai media kultur mikroba (Ortez, 2005).

\section{Kultul Mikroba}

$\begin{array}{ccc}\text { Masing - masing mikroba yang } \\ \text { sudah dikultur } & \text { (Escherichia coli, }\end{array}$ Staphylococcus aureus dan Candida albicans) ditambahkan sebanyak $100 \mu \mathrm{L}$ kedalam masing-masing tabung reaksi yang sudah diisi media cair B1 sebanyak $1 \mathrm{~mL}$. Masing-masing tabung reaksi ditutup dengan aluminium foil dan dimasukkan kedalam inkubator selama 1x24 jam dengan suhu $37^{\circ} \mathrm{C}$.

\section{Pembuatan Kontrol Positif dan Kontrol Negatif}

Kontrol positif dalam pengujian aktivitas antimikroba ini menggunakan kloramfenikol paper disc. Kontrol negatif yang digunakan dalam penelitian ini menggunakan metanol untuk menguji apakah pelarut metanol memberikan pengaruh terhadap aktivitas daya hambat, dengan cara membuat larutan stok metanol dengan mengambil sebanyak $200 \mu \mathrm{L}$ 
metanol kemudian ditotolkan pada kertas cakram. Kontrol negatif digunakan sebagai pembanding.

\section{Pembuatan Larutan Uji}

Larutan uji dibuat dengan cara melarutkan ekstrak etanol Lissoclinum patella sebanyak $1 \mathrm{mg}$ ke dalam metanol $200 \mu \mathrm{L}$ sehingga menghasilkan konsentrasi larutan uji sebesar $250 \mu \mathrm{g} / 50 \mu \mathrm{L}$. Perlakuan yang sama dilakukan untuk fraksi n-Heksan, fraksi kloroform dan fraksi metanol (Ortez, 2005).

\section{Pembuatan Media Agar B1}

Pepton 0,5 g, ekstrak daging (meat extract) 0,3 g, natrium klorida 0,3 g, nutrient agar 1,5 g dan dilarutkan dalam akuades sebanyak $100 \mathrm{~mL}$ menggunakan Erlenmeyer, dikocok sampai homogen. Media yang telah homogen kemudian disterilkan dengan menggunakan autoklaf pada suhu $121^{\circ} \mathrm{C}$ selama 15 menit. Media agar B1 siap digunakan untuk uji aktivitas antimikroba.

\section{Pengujian Aktivitas Antimikroba}

Metode yang digunakan dalam penelitian ini yaitu metode difusi agar (disc diffusion Kirby and Bauer). Pada pengujian aktivitas antimikroba digunakan kertas cakram yang berukuran $6 \mathrm{~mm}$ dengan daya serap $50 \mu \mathrm{L}$ tiap cakram. Suspensi mikroba kemudian diinokulasikan ke dalam media dan dihomogenkan. Kemudian media yang telah diinokulasi mikroba dituangkan ke dalam cawan petri sebanyak $100 \mathrm{~mL}$ dan ditunggu hingga media mengeras. Sampel yang telah ditentukan konsentrasinya (250 $\mu \mathrm{g} / 50 \mu \mathrm{L})$ ditotolkan pada masing-masing cakram dengan menggunakan mikropipet. Masing-masing cawan petri diberi label dan nomor sampel yang sesuai. Kertas cakram yang telah ditotolkan sampel uji Tunikata Lissoclinum patella diletakkan ke dalam cawan petri dengan pinset lalu diinkubasi selama 1 x 24 jam (Ortez, 2005).

\section{Pengamatan dan Pengukuran Zona Hambat}

Pengamatan dilakukan setelah 24 jam masa inkubasi. Daerah pada sekitaran cakram menunjukkan kepekaan mikroba terhadap antibiotik atau bahan antimikroba yang digunakan sebagai bahan uji yang dinyatakan dengan diameter zona bening. Diameter zona bening diukur dalam satuan millimeter (mm) menggunakkan jangka sorong dengan cara diukur diameter zona bening horizontal ditambahkan dengan diameter zona bening vertikal lalu dibagi dua. Kemudian zona bening yang telah diukur, dibandingkan berdasarkan pedoman Davis dan Stout (1971).

\section{Teknik Pengolahan Data dan Analisis Data}

Teknik pengolahan data dilakukan dengan model penyajian dalam bentuk tabel dan gambar, grafik dan dianalisis secara deskriptif. Aktivitas antibakteri diukur menggunakan penggaris besi skala millimeter berdasarkan zona hambatan yang terbentuk

\section{HASIL DAN PEMBAHASAN}

\section{Ektraksi dan Fraksinasi}

Sampel Tunikata Lissoclinum patella yang diambil dari Perairan Desa Tumbak, Kecamatan Posumaen, Minahasa Tenggara, 


\section{PHARMACON- PROGRAM STUDI FARMASI, FMIPA, UNIVERSITAS SAM RATULANGI,}

Volume 8 Nomor 4 November 2019

Sulawesi Utara. Sampel diambil menggunakan alat bantu Scuba Diving. Sampel lalu dibersikan. Kemudian sampel dipotong kecil kecil. Sampel dipotong kecilkecil bertujuan untuk memperbesar ukuran permukaan sampel karena semakin luas permukaan sampel maka interaksi antara sampel dan pelarut semakin besar sehingga proses ekstraksi berjalan optimal (Ncube $e t$ al., 2008). Sampel kemudian dikstraksi dengan menggunakan metode maserasi. Tujuan pemilihan metode maserasi karena cara pengerjaan dan peralatannya yang sederhana, tidak dilakukan pemanasan sehingga dapat mencegah terjadinya penguraian zat aktif yang terkandung dalam sampel akibat pengaruh suhu dan senyawa yang tidak tahan pemanasan (Sa'adah et al., 2015). Metode maserasi sangat menguntungkan dalam isolasi senyawa bahan alam maupun bahan laut, karena dengan perendaman sampel, terjadi pemecahan dinding sel karena adanya perbedaan tekanan didalam dan diluar sel sehingga metabolit sekunder dalam sitoplasma larut dalam pelarut organic dan ekstraksi senyawa akan sempurna karena pedendaman yang akan dilakukan dapat diatur (Lenny, 2006). Proses maserasi dilakukan 3×24 jam dengan dua kali remaserasi atau pergantian pelarut yang baru. Untuk mendapatkan penyarian yang maksimal, agar senyawa yang terdapat didalam sampel dapat terekstrak secara menyeluruh maka dilakukan remaserasi atau pengulangan dengan penggantian pelarut sebanyak tiga kali. Proses maserasi dilakukan berulangkali dengan jumlah pelarut yang lebih kecil, lebih efisien dibandingkan dilakukan sekali dengan jumlah pelarut yang banyak (Khopkar, 2008).

Maserasi dilakukan dengan menggunakan pelarut etanol $96 \%$. Menurut Suryato (2012), pemilihan pelarut pada umumnya dipengaruhi oleh beberapa factor antara lain selektivitas, kelarutan, dan titik didih. Etanol 96\% dipilih karena selektif, tidak toksik, ekonomis dan kemampuan penyariannya yang tinggi sehingga dapat menyari senyawa yang bersifat non-polar, semi polar dan bersifat polar. Pelarut etanol 96\% lebih mudah masuk berpenetrasi ke dalam dinding sel sampel daripada pelarut etanol dengan kosentrasi lebih rendah. Sehingga menghasilkan ekstrak yang pekat. Hasil maserasi selanjutnya diuapkan menggunakan oven dengan suhu $40^{\circ} \mathrm{C}$ sehingga didapat ekstrak etanol.

Ekstrak etanol diperoleh 11,4 g dengan rendemennya $2,85 \%$ dan berwarna kuning kecoklatan yang kemudian diambil sebanyak $6 \mathrm{~g}$ untuk difraksinasi dengan menggunakan tiga pelarut yang berbeda berdasarkan tingkat kepolaran. Pelarut yang digunakan yaitu n-Heksan, kloroform dan metanol. Penggunaan pelarut n-Heksan untuk melarutkan senyawa yang bersifat non polar, pelarut kloroform untuk melarutkan senyawa yang bersifat semi polar dan pelarut metanol untuk melarutkan senyawa yang bersifat polar. Selanjutnya, Ekstrak etanol sebanyak $6 \mathrm{~g}$ dengan menggunakan pelarut metanol sebanyak $100 \mathrm{~mL}$, lalu dipartisi dengan menggunakan pelarut $n$ Heksan 100 mL kemudian lapisan n-Heksan ditampung ke dalam wadah, lalu diuapkan dengan oven dan diperoleh fraksi n-Heksan 0,1495 g rendemennya $5,98 \%$ dan warna fraksi berwarna coklat kehijauan. Lapisan 
Metanol kemudian dipartisi kembali dengan pelarut kloroform sebanyak $200 \mathrm{~mL}$ dan sebelumnya ditambahkan akuades $100 \mathrm{~mL}$. Penambahan akuades tersebut dimaksudkan memperjelas batas lapisan tiap pelarut. Selanjutnya, Lapisan kloroform dan lapisan metanol ditampung kedalam wadah dan diuapkan menggunakan oven. Fraksi kloroform diperoleh $0,0498 \mathrm{~g}$ dengan rendemen yang diperoleh 1,99\% warna filtrat berwarna coklat, fraksi metanol $0,2268 \mathrm{~g}$ diperoleh rendemennya $9,07 \%$ dengan warna filtrat coklat kehijauan. Pelarut metanol yang dipartisi dengan pelarut $\mathrm{n}$-Heksan membentuk dua lapisan yaitu lapisan n-Heksan yang berada diatas dan lapisan metanol berada dibawah, pelarut metanol dipartisi kembali dengan pelarut kloroform terbentuk dua lapisan yaitu lapisan metanol yang berada di atas dan lapisan klorofom yang berada bawah. Posisi sebuah pelarut berada di atas atau di bawah pada saat proses fraksinasi dipengaruhi oleh berat jenis masing masing pelarutnya.

Tabel 1. Rendemen fraksi Tunikata Lissoclinum patella.

\begin{tabular}{ccccc}
\hline No & Sampel & $\begin{array}{c}\text { Berat } \\
(\mathbf{g})\end{array}$ & $\begin{array}{c}\text { Rendemen } \\
(\mathbf{\%})\end{array}$ & Warna \\
\hline 1. & EE & 11,4 & 2,85 & $\begin{array}{c}\text { Kuning } \\
\text { kecoklatan }\end{array}$ \\
\hline 2. & FH & 0,1495 & 5,98 & $\begin{array}{c}\text { Coklat } \\
\text { kehijauan }\end{array}$ \\
\hline 3. & FK & 0,0498 & 1,99 & Coklat \\
\hline 4. & FM & 0,2268 & 9,07 & $\begin{array}{c}\text { Coklat } \\
\text { kehijauan }\end{array}$ \\
\hline
\end{tabular}

Perbedaan nilai rendemen ini disebabkan oleh perbedaan jenis pelarut yang digunakan. Pelarut yang berbeda akan melarutkan senyawa-senyawa yang berbeda tergantung tingkat kepolarannya. Sehingga, jumlah ekstrak yang dihasilkan pun juga tergantung jenis pelarutnya. Jumlah rendemen terbesar ditunjukkan pada fraksi metanol dengan nilai sebesar $9,07 \%$. Tinginya suatu rendemen yang terdapat pada pelarut mengindikasikan pelarut persebut mampu mengekstrak lebih banyak komponen bioaktif yang memiliki sifat kepolaran yang lebih tinggi. $\mathrm{Hal}$ ini menunjukkan bahwa terdapat banyak komponen bioaktif yang bersifat polar dalam Tunikata Lissoclinum patella.

\section{Uji Aktivitas Antimikroba Tunikata Lissoclinum patella}

Pengujian aktivitas antimikroba dari ekstrak etanol, fraksi metanol, fraksi nheksan, dan fraksi kloroform pada mikroba uji Escherichia coli, Staphylococcus aureus, dan Candida albicans menggunakan metode difusi agar (difusi Kirby dan Bauer). Metode ini menjadi pilihan karena untuk tujuan klinis dengan mempertimbangkan kesederhanaan teknik, ketelitian, metode serbaguna bagi semua bakteri patogen yang tumbuh cepat dan sering digunakan dalam uji kepekaan antibiotik dalam program pengendalian mutu. menggunakan metode difusi agar disc diffusion test.

Metode ini juga dipilih karena mudah, murah dan tidak memerlukan alat khusus. Metode difusi agar adalah metode yang dilakukan dengan pengukuran dan pengamatan diameter zona bening yang terbentuk disekitar cakram yang berisi antimikroba yang telah diinokulasi mikroba.

Mikroba uji yang digunakan yaitu Escherichia coli mewakili bakteri Gram negatif, Staphylococcus aureus mewakili bakteri Gram positif, dan Candida albicans 


\section{PHARMACON- PROGRAM STUDI FARMASI, FMIPA, UNIVERSITAS SAM RATULANGI,}

Volume 8 Nomor 4 November 2019

mewakili jamur. Tujuan penggunaan mikroba tersebut untuk mengetahui bahwa apakah ekstrak dan fraksi dari Lissoclunim patella memiliki aktivitas antimikroba serta untuk mengetahui spektrum dari aktivitas antimikroba Lissoclunim patella apakah memiliki spektrum luas, yaitu dapat membunuh banyak jenis mikroba yaitu bakteri Gram positif dan Gram negatif, atau spektrum sempit yaitu yang hanya membunuh salah satu dari Gram positif atau Gram negatif.

Dalam pengujian, hasil yang didapat yaitu adanya zona hambat disekeliling cakram berukuran $6 \mathrm{~mm}$ yang ditandai dengan zona bening, hal ini menunjukkan adanya kepekaan mikroba terhadap ekstrak atau fraksi dari Tunikata Lissoclinum patella. Pengamatan dilakukan setelah inkubasi pada suhu $37^{\circ} \mathrm{C}$ selama $1 \times 24$ jam dengan pengulangan sebanyak tiga kali. Dilakukan pengulangan untuk lebih mengakuratkan hasil yang diperoleh. Konsentrasi yang digunakan yaitu $250 \mu \mathrm{g}$ dalam setiap kertas cakram yang memiliki daya serap $50 \mu \mathrm{g}$ dari sampel Tunikata Lissoclinum patella terhadap mikroba uji Escherichia coli, Staphylococcus aureus dan Candida albicans. Hasil pengukuran diameter zona hambat dari ekstrak etanol, fraksi n-Heksan, fraksi kloroform dan fraksi methanol terhadap mikroba uji Escherichia coli, Staphylococcus aureus, dan Candida albicans ditunjukkan pada Tabel 2.
Tabel 2. Hasil pengujian ekstrak dan fraksi Tunikata Lissoclinum patella terhadap mikroba uji Escherichia coli, Staphylococcus aureus dan Candida albicans.

\begin{tabular}{|c|c|c|c|c|c|c|c|}
\hline \multicolumn{8}{|c|}{ Diameter Zona Hambat (m m) } \\
\hline \multirow{2}{*}{ Mikroba } & \multirow{2}{*}{ Ulangan } & \multirow{2}{*}{ EE } & \multirow{2}{*}{ FH } & \multirow{2}{*}{ FK } & \multirow{2}{*}{ FM } & \multicolumn{2}{|c|}{ Kontrol } \\
\hline & & & & & & $\mathbf{K}+$ & $\mathbf{K}-$ \\
\hline \multirow{5}{*}{$\begin{array}{c}\text { Escherichia } \\
\text { Coli }\end{array}$} & I & 7,00 & 7,00 & 7,00 & 7,00 & 24,00 & 0,00 \\
\hline & II & 7,00 & 9,00 & 7,00 & 7,00 & & \\
\hline & III & 7,00 & 7,00 & 7,00 & 7,00 & & \\
\hline & Jumlah & 21,00 & 23,00 & 21,00 & 21,00 & & \\
\hline & Rata-rata & 7,00 & 7,67 & 7,00 & 7,00 & & \\
\hline \multirow{5}{*}{$\begin{array}{c}\text { Staphylococcus } \\
\text { aureus }\end{array}$} & $\mathrm{I}$ & 7,00 & 8,00 & 8,00 & 8,00 & 23,00 & 0,00 \\
\hline & II & 7,00 & 7,00 & 8,00 & 8,00 & & \\
\hline & III & 7,00 & 7,00 & 8,00 & 7,00 & & \\
\hline & Jumlah & 21,00 & 22,00 & 24,00 & 23,00 & & \\
\hline & Rata-rata & 7,00 & 7,33 & 8,00 & 7,67 & & \\
\hline \multirow{5}{*}{$\begin{array}{l}\text { Candida } \\
\text { Albicans }\end{array}$} & I & 8,00 & 8,00 & 8,00 & 7,00 & 20,00 & 0,00 \\
\hline & II & 8,00 & 8,00 & 8,00 & 8,00 & & \\
\hline & III & 7,00 & 8,00 & 8,00 & 8,00 & & \\
\hline & Jumlah & 23,00 & 24,00 & 24,00 & 23,00 & & \\
\hline & Rata-rata & 7,67 & 8,00 & 8,00 & 7,67 & & \\
\hline
\end{tabular}

Dalam pengujian digunakan kontrol positif dan kontrol negatif. Kontrol positifnya menggunakan Kloramfenikol paper disc. Kloramfenikol dipilih sebagai kontrol positif yang merupakan larutan pembanding efek antara obat antimikroba baku dengan larutan ekstrak uji dalam hal ini ascidian Lissoclinum patella. Kontrol positif berfungsi sebagai kontrol dari zat uji, dengan membandingkan diameter daerah hambat yang terbentuk (Dwijendra, 2014). Pemilihan antibiotik kloramfenikol sebagai kontrol positif karena memiliki aktivitas antimikroba dengan spektrum luas yaitu dapat menghambat pertumbuhan bakteri gram negatif, gram positif dan jamur. Kloramfenikol memiliki aktivitas antimikroba yang lebih besar terhadap mikroba uji dibandingkan ekstrak etanol, fraksi n- heksan, fraksi kloroform dan fraksi metanol. 


\section{PHARMACON- PROGRAM STUDI FARMASI, FMIPA, UNIVERSITAS SAM RATULANGI,}

Volume 8 Nomor 4 November 2019

Diameter zona bening yang dihasilkan kloramfenikol pada Escherichia coli $(24 \mathrm{~mm})$, Staphylococcus aureus (23 $\mathrm{mm})$ dan Candida albicans (20 mm). Kontrol negatif digunakan untuk mengetahui ada tidaknya pengaruh pelarut terhadap pertumbuhan mikroba uji sehingga dapat diketahui bahwa aktivitas yang ditunjukan oleh ekstrak dan fraksi ialah zat yang terkandung dalam sampel bukan berasal dari pelarut yang digunakan. Kontrol negatif yang digunakan yaitu metanol. Dari hasil yang diperoleh, kontrol negatif tidak memiliki daya hambat antimikroba terhadap ketiga mikroba uji. Hal ini menunjukkan bahwa aktivitas yang ditunjukkan oleh ekstrak dan fraksi tunkata Lissoclinum patella, murni dari senyawa yang ada dalam sampel dan bukan dari pelarut. Pada penelitian ini, ekstrak etanol, fraksi kloroform, fraksi n-Heksan dan fraksi metanol menunjukkan ekstrak dan fraksi yang efektif untuk menghambat pertumbuhan mikroba. Respon berbeda diperoleh dari setiap mikroba uji terhadap senyawa antimikroba. Dalam tabel 3 bakteri Gram positif yaitu Staphylococcus aureus cenderung lebih sensitif terhadap komponen antimikroba lebih khusus dalam fraksi kloroform dan metanol dibandingkan bakteri Gram negatif. Hal tersebut disebabkan karena adanya perbedaan kepekaan pada Gram positif, Gram negatif dan jamur terhadap senyawa yang ada didalam ekstrak dan fraksi Tunikata Lissoclinum patella. Struktur dinding sel bakteri Gram positif lebih sederhana sehingga memudahkan senyawa antimikroba untuk masuk ke dalam sel dan menemukan sasaran untuk bekerja, sedangkan struktur dinding sel bakteri Gram negatif lebih kompleks dan berlapis tiga, yaitu lapisan luar berupa lipoprotein, lapisan tengah yang berupa peptidoglikan, dan lapisan dalam lipopolisakarida (Pelczar \& Chan,1986).

Diameter Zona bening yang ditunjukkan Jamur uji Candida albicans cenderung lebih besar dibandingkan bakteri uji pada ekstrak etanol dan fraksi n-Heksan walaupun untuk fraksi kloroform dan fraksi metanol terdapat nilai diameter zona bening yang sama pada bakteri uji. Berbeda dengan bakteri, jamur mempunyai struktur dinding sel yang sangat kompleks dengan rangka dasar yang terdiri dari polisakarida kristalin, kitin, dan B-glukan, dan suatu matriks yang terdiri dari polisakarida amorf dan kompleks proteinsakarida. Kitin dan B-glukan bertanggung jawab terhadap mekanismedinding sel jamur (Siswandono danBambang, 1995).

Diameter zona hambat yang ditunjukkan ekstrak etanol terhadap setiap mikroba uji Escherichia coli, Staphylococcus aureus dan Candida albicans dikategorikan sedang. Hal ini juga menunjukkan adanya senyawa aktif yang memiliki aktivitas antimikroba spektrum luas yang dapat menghambat pertumbuhan bakteri Gram positif Staphylococcus aureus, bakteri Gram negatif Staphylococcus aureus dan jamur Candidaalbicans.

Diameter zona hambat yang ditunjukkan pada fraksi n-Heksan terhadap mikroba uji Escherichia coli, Staphylococcus aureus dan Candida albicans dikategorikan sedang. Pada fraksi n-Heksan jamur Candida albicans memiliki nilai yang paling besar dibandingkan dengan esktrak dan fraksi lainnya dalam mengambat 
pertumbuhan masing-masing mikroba. Menurut Roihanah et al. (2012) pelarut nHeksan adalah pelarut yang paling efektif dalam menghambat pertumbuhan mikroba, hal ini disebabkan karena senyawa bioaktif yang terkandung pada Tunikata mudah larut dalam pelarut non polar yang dapat berfungsi sebagai bahan antimikroba.

Diameter zona hambat yang ditunjukkan pada fraksi kloroform, terhadap mikroba uji Escherichia coli, Staphylococcus aureus dan Candida albicans dikategorikan sedang. Hal ini juga menunjukkan adanya senyawa aktif yang memiliki aktivitas antimikroba spektrum luas yang dapat menghambat pertumbuhan bakteri Gram positif Staphylococcus aureus, bakteri Gram negatif Escherichia coli dan jamur Candida albicans.

Diameter zona hambat yang ditunjukkan pada fraksi metanol lebih kecil bila dibandingkan dengan fraksi n-Heksan yang ada pada Gram negatif Escherichia coli dan jamur Candida albicans. Walaupun pada fraksi metanol jika dilihat dari perbandingan persen rendemen mengandung senyawa metabolit sekunder yang lebih banyak daripada fraksi n-Heksan. Menurut Dwijendra et al. (2014) Hal ini mungkin disebabkan karena adanya kerja yang tidak sinergis antara senyawa metabolit sekunder dalam peranannya sebagai antimikroba.

Dalam pengukuran diameter Zona bening dalam suatu ekstrak atau fraksi terhadap tiga mikroba uji terdapat daerah zona bening yang tidak sama besar pada saat pengulangan terjadi pada fraksi n-Heksan terhadap Gram negatif Escherichia coli, fraksi n-Heksan dan fraksi metanol terhadap Gram positif Staphylococcus aureus, ekstrak etanol dan Fraksi metanol terhadap jamur Candida albicans. Hal ini dipengaruhi oleh daya serap yang diserap pada saat proses menotolan sampel pada paper disc. Menurut Bhorgin (2014), besar kecilnya daerah hambat dipengaruhi oleh laju pertumbuhan mikroorganisme, kemampuan dan laju difusi bahan aktif pada medium, kepekaan mikroorganisme terhadap zat aktif serta ketebalan dan viskositas medium.

\section{KESIMPULAN}

Ekstrak dan fraksi Tunikata Lissoclinum patella memiliki aktivitas antimikroba. Berdasarkan hasil penelitian yang telah dilakukan dapat disimpulkan bahwa pada ekstrak etanol, fraksi n-Heksan, fraksi Kloroform dan fraksi metanol dari Tunikata Lissoclinum patella terhadap mikroba uji Escherichia coli, Staphylococcus aureus dan Candida albicans memiliki kategori kekuatan daya hambat sedang.

\section{SARAN}

Perlu dilakukan penelitian lebih lanjut dengan uji antioksidan dari Tunikata Lissoclinum patella.

\section{DAFTAR PUSTAKA}

Bhorgin, A. J. and Uma, K. 2014. Antimicrobial Activity of Earthworm Powder (Lampito mauritii). Int Jorunal of Current Microbiology and Applied Science. 3 (1): 437-443.

Davis, W.W., and Stout, T.R. 1971. Disc Plate Methods of Microbiological Antibiotic Assay. Journal Microbiology. 22(4): 659-665. 
PHARMACON- PROGRAM STUDI FARMASI, FMIPA, UNIVERSITAS SAM RATULANGI,

Volume 8 Nomor 4 November 2019

Khoeri, M.M. 2009. Bioprospeksi Bakteri Simbion pada Tunikata Didemnum molle dari Perairan Pul au Sambangan Karimunjawa Jepara. Universitas Dipoengoro, Semarang.

Khopkar, S.M. 2008. Konsep Dasar Kimia Analitik. UI Press, Jakarta.

Lenny, S. 2006. Senyawa Flavonoida, Fenilpropanoida dan Alkaloida. FMIPA Universitas Sumatera Utara, Medan.

Ncube, N.S., Afolayan, A.J., Okoh, A.I. 2008. Assesement Techniques of Antimicrobial Properties of Natural Compounds of Plant Origin: Current Methods and Future Trends. Africa Journal of Biotechnology. 7(12): 3032.

Nofiani, Risa. 2008. Urgensi dan Mekanisme Biosintesis Metabolit Sekunder Mikroba Laut. Jurnal Natur Indonesia. 10 (2): 120-125.

Ortez, J.H. 2005. Disk Diffusion Testing in Manual of Antimicrobial Susceptibility Testing. Marie B. Coyle (Coord.Ed). American Society for Microbiology.

Pelczar, M.J., Chan, E.C.S. 1986. Dasardasar Mikrobiologi 2. Universitas Indonesia Press, Jakarta.

Rasyid, A. 2008. Biota Laut Sebagai Sumber Obat-obatan. Oseana, 33(1): 11-18.

Roihana S, Sukoso, Andayani S. Aktivitas Antibakteri Ekstrak Teripang (Holoturia Sp) Terhadap Bakteri Vibrio Harveyi Secara In-Vitro. [skripsi]. Fakultas Perikanan dan Ilmu Kelautan. Universitas Brawijaya. Malang. 2012.
Sa'adah, H., dan Nurhasnawati, H. 2015. Perbandingan Pelarut Etanol dan Air Pada Pembuatan Ekstrak Umbi Bawang Tiwai (Eleutherine Americana Merr). Jurnal Ilmiah Manuntung. 1(2): 149- 153.

Siswandono dan Bambang, S. 1995. Kimia Medisinal. Erlangga, Surabaya.

Suryanto, E. 2012. Fitokimia Antioksidan. Putra Media Nusantara, Surabaya.

Thakur, N. L, and Muller, W.E.G. 2004. Biotechnological Potential of Marine Sponges. Jurnal Current Science. 86:1506-1512.

Wang, W., and Namikoshi, M. 2007. Bioactive Nitrogenous Metabolites from Ascidians. Heterocycles. 74: 53-88

Wewengkang, D.S., Sumilat, D.A., dan Rotinsulu, H. 2014. Sitotoksisitas Ekstrak Kasar Ascidian dari Pulau Bunaken. Jurnal LPPM Bidang Sains dan Teknologi. 1(1): 86-89 